\title{
Vênus, Crucifixos, Corações e Arcanjos: Arte e reforma católica entre Roma, Paris, Munique, Lisboa e Belém do Pará (1860- 1890) $)^{*}$
}

\author{
Venus, Crucifixes, Hearts and Archangels: Art and catholic reform \\ between Rome, Paris, Munich, Lisbon and Belém do Pará (1860-1890)
}

\author{
Aldrin Moura de Figueiredo ${ }^{1}$ \\ Silvio Ferreira Rodrigues ${ }^{2}$
}

RESUMO

Este artigo analisa o papel da arte sacra e religiosa na Amazônia no contexto do movimento de renovação do catolicismo brasileiro no século XIX em perspectiva internacional. Para isso, analisa o programa iconológico levado a termo pelo bispo do Pará D. Antônio de Macedo Costa, entre as décadas de 1860 e 1880, em especial pela substituição de pinturas do século XVIII por obras consideradas modernas e de acordo com os novos parâmetros artísticos do catolicismo romano. Essa reforma na Sé de Belém do Pará, juntamente com outras realizadas no mesmo período do pontificado de Pio IX, perfaz um programa iconológico e um corpus narrativo de fundo artístico e sagrado, que são testemunhos da pedagogia e dos debates políticos na história do catolicismo mundial do século XIX, a partir das diretrizes romanas.

Palavras-chave: D. Macedo Costa, Pio IX, arte italiana, romanização, pintura religiosa.

\section{ABSTRACT}

This article analyzes the role of sacred and religious art in Amazonia in the context of the Brazilian catholic renovation movement in the nineteenth century, from an international perspective. For that, the article analyses the iconological programme carried out by the Bishop of Pará D. Antônio de Macedo Costa, between the decades of 1860 and 1880 , with special focus on the substitution of 18th century paintings by contemporary ones, at the time considered more 'modern' and in line with the new artistical parameters of Roman Catholicism. This reform at Belém's Cathedral, together with others in the same period,

\footnotetext{
* Essa pesquisa é parte de um projeto mais amplo sobre a circulação de artistas estrangeiros na Amazônia entre os séculos XIX e XX, que contou com o apoio do CNPq, Capes, Intercâmbio Santander, a quem os autores agradecem.

1 - Doutor em História/UNICAMP. Professor da Faculdade de História da Universidade Federal do Pará e Pesquisador do CNPq. E-Mail: figueiredoaldrin@gmail.com

2 - Doutor em História/UFPA. Professor da Escola de Aplicação da Universidade Federal do Pará.
} 
throughout Pio IX's pontificate, constitutes an iconological programme as well as an artistical and sacred narrative body, which testify to the pedagogical and political debates on the history of the Catholic world in the 19th century, from Roman guidelines.

Keyword: D. Macedo Costa, Pius IX, Italian art, romanization, religious painting.

\section{A cultura material da fé: Arte e romanização ou mil vezes um Cruxifixo ejamais uma Vênus}

Em todo o século XIX, a igreja católica brasileira se esforçou para controlar o uso das imagens sagradas no interior dos templos e no cotidiano das práticas do culto religioso. No entanto, sempre dificil foi estabelecer com os fieis a clássica diferenciação entre a arte sacra, destinada ao rito litúrgico, e a arte religiosa, destinada a conduzir a uma atitude aparentemente sem grandes compromissos com a expressão divina, mais afeita portanto à expressão plástica do sagrado. De fato, essa diferenciação não parecia tão clara mesmo para os membros da hierarquia católica. Para ser ter uma ideia disso, em 1864, o principal jornal católico do Pará, divulgava um presente dado ao papa Pio IX pelo bispo de Orleans, representando a "fisionomia tradicional de nosso divino redentor", feito pelo artista francês Monsieur Van Cleef. Tratava-se de um "Busto de Nosso Senhor", com a inscrição: "Feito segundo um camafeu existente em Roma, e encomendado pelo imperador Tibério César, contemporaneo de Jesus Cristo (VARIEDADES, 1864, p.6-7) ${ }^{3}$. Essa peça de arte religiosa teria rodado o mundo. Até o século XV, teria ficado em poder dos imperadores de Constantinopla ${ }^{4}$, quando foi adquirido pelo sultão Bajazet II (1447-1512) que o ofereceu ao papa Inocencio VIII (1432-1492), quando negociava o resgate de seu irmão Zizimo, cativo dos cristãos. Também teria servido como modelo para Rafael Sanzio (1483-1520), de onde Van Cleef, na década de 1860, teria buscado o "mesmo tipo ideal, à mesma beleza divina, das que foram traçadas pelo pincel do gênio imortal de Urbino" (VARIEDADES, 1864, p.7).

Tomando essa história de um objeto artístico de caráter religioso, o bispo do Pará, D. Antônio de Macedo Costa arremata: "Nós desejaríamos que no Pará e no resto do Brasil se divulgasse essa bela obra em vez de outras profanas". Obras essas que "às vezes indecentes, se introduzem no seio das famílias" (VARIEDADES, 1864, p.7). Mais até do que objeto de culto, imagens como o busto de Cristo de Van Cleef eram vistas com traço de civilização, de experiência com o sagrado e também de enlace com a doutrina católica (ALEXANDRE-BIDON,

\footnotetext{
${ }^{3}$ Jan van Cleef (1646 - 1716) foi um pintor flamengo de origem holandesa. Van Cleef nasceu em Venlo, no ducado de Guelders. Foi discípulo de Luigi Primo (Gentile) e Gaspard de Craeyer. Quando Craeyer morreu, Cleef foi encarregado de completar o trabalho de seu mestre nas igrejas e terminar os desenhos para a tapeçaria encomendada por Louis XIV. Foi pintor prolífico de obras religiosas, como testemunham as igrejas e conventos em Flandres e Brabante. Seus biógrafos, consideram seu estilo mais italiano do que flamengo, o que, por certo, adensa o interesse por sua obra pelo bispo do Pará. ${ }^{4}$ Constantino XI (1404-1453), membro da dinastia Paleólogo, foi o último imperador bizantino, desde 1449 até sua morte. Seu reinado configurou o fim do Império Romano do Oriente, com o ataque cada vez mais evidente dos turcos otomanos (SCHUTTER, 2016).
} 
1998). Esse discurso por meio das imagens fazia parte de um movimento de reforma da igreja, que então acontecia num plano mundial, com destaque para a América Latina, conhecido por romanização. A semântica do texto também exemplifica a maneira como a cúpula católica brasileira procurava maior aproximação de seu clero e das mundo das artes às matrizes e concepções artísticas em voga no episcopado romano. D. Macedo Costa voltava sua atenção contra o catolicismo tradicional, de cunho popular, a fim de discipliná-lo por meio de palavras, atos e imagens.

Era necessário afastar o profano, e seu universo mundano, do sagrado, com sua aura santificada. As obras de arte, as literaturas e mesmo as mitologias eram um bom caminho a percorrer nessa seraparação cognitiva dos mundos. $O$ fruto do paganismo seria decorativo; o fruto do cristianismo era, então, visto como arte religiosa, naquele contexto sinônimo de arte sacra. Os exemplos são inúmeros e para todos os gostos, no contexto da capital do Pará da década de 1860. Talvez Vênus fosse o modelo mais eloquente dessa mitologia pagã, fosse por sua bela imagem, fosse pelos atributos do amor e da paixão (LIASSIS, 2015). Em 1860, o confeiteiro Antonio Joaquim Ferreira, promovia seus famosos biscoitos "Peitos de Vênus" à venda em sua padaria na Rua Nova de Santana (PADARIA, 1860, p.4). Ainda em abril de 1860, o amanuense Bernardino Rodrigues Valente do Couto, anunciava a relação das pessoas despachadas na tripulação da canôa Vênus, para a cidade de Porto de Moz, no baixo Amazonas paraense (REPARTIÇÃO, 1860, p.1). Vênus também, obviamente, era muito lembrada como a deusa romana do amor, da beleza e do comércio local. Numa festa de $C l u b$, uma mulher poderia aparecer "linda, muito linda, elegante". Seus atributos físicos: "olhar inquieto, labio inflamado, face chamejante". Em festa à fantasia, era trazida pelo braço de um "urso cabeludo". Toda a cena tinha uma explicação: "a razão mitológica". Afinal, Vênus não teria sido "a mulher de Plutão"? (VARIEDADE, 1867, p.2; ARSCOTT; SCOTT, 2000). Como a deusa da antiguidade, a Vênus no Pará era símbolo de mulher bonita e nome de loja especializada em moda. Por exemplo a casa comercial Vênus Paraense, era anunciada na edição de um almanaque mercantil do Pará de 1869, pelo comerciante Antonio Joaquim Fernandes. Sua especialidade eram os tecidos e fazendas importados da Europa, postos à venda em confortável prédio à rua dos Mercadores (ALMACH, 1869, p.216). 


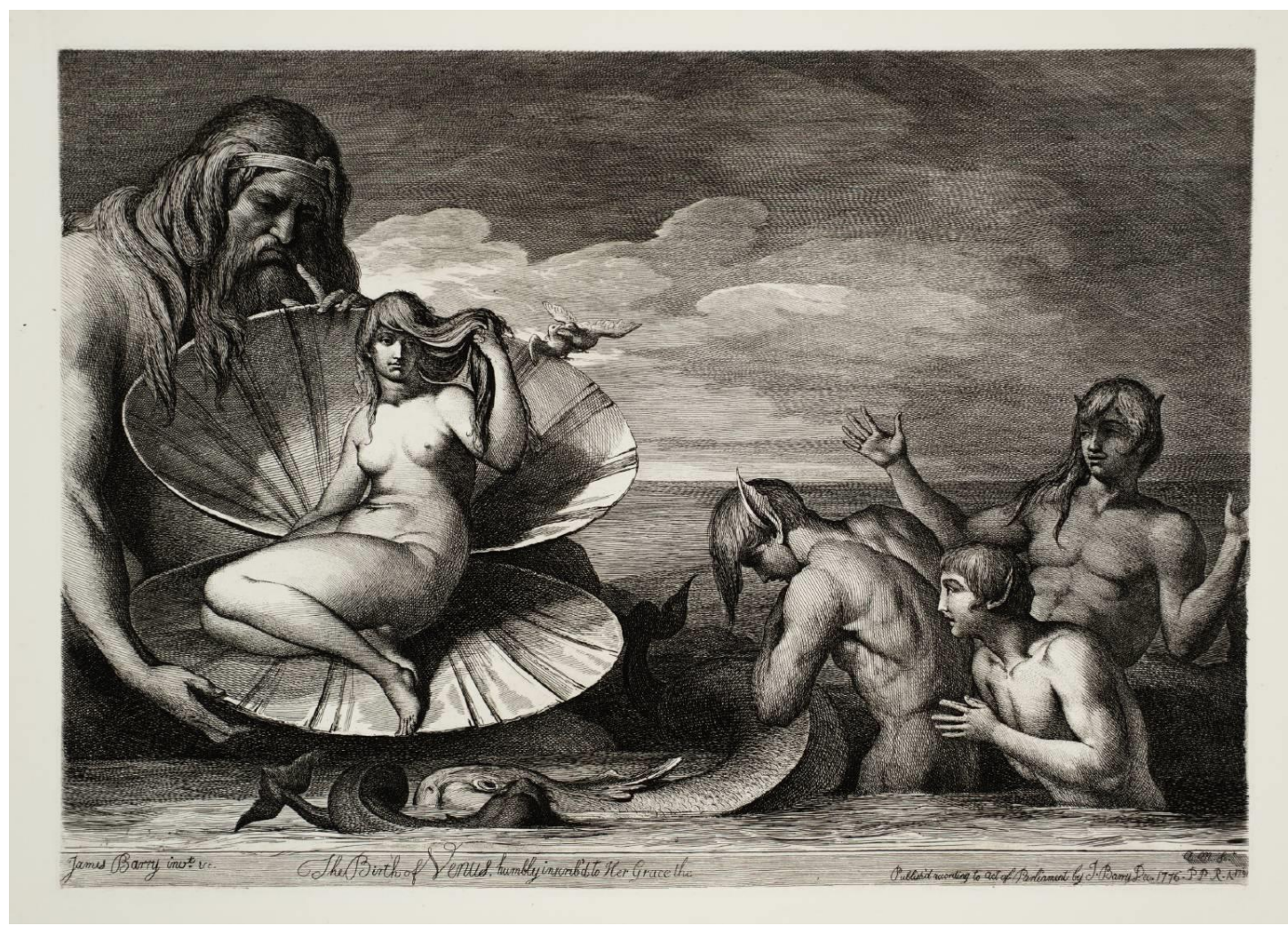

Figura 1: James Barry (1741-1806), Nascimento de Vênus, água-tinta, c.1776 (Acervo Cônego José Andrade Pinheiro, Col. Particular, Belém)

Parecia claro o lugar de uma imagem como a da deusa Vênus no imaginário social de uma cidade como Belém do Pará. O próprio cônego José Andrade Pinheiro, reconhecido intelectual da igreja do Pará, nomeado em 1889 vigário das paróquias de São Miguel do Guamá e Ourém, guardava entre seus objetos de arte uma água tinta como tema do nascimento de Vênus, de James Barry (FIGURA 1), talvez adquirida de alguns dos muitos comerciantes ingleses que viviam em Belém, nos meados do século XIX. No entanto, o bispo não parecia assim tão satisfeito. Era necessário comparar. Semelhança e diferença estão longe de configurar aportes do senso comum na história da arte. $O$ método comparativo parece mesmo ser uma espécie de esteio da disciplina com inumeros debates sobre problemas, abordagens e procedimentos naquilo que poderíamos chamar de embate direto com as imagens (ELSNER, 2017). O que o bispo do Pará sugeria, em plena década de 1860, era na verdade uma espécie de confrontação formal de imagens com implicações políticas e morais, mas que atingiam, sobretudo, percepções acerca da cultura e de certa noção de civilização. Publicado em 29 de dezembro de 1863, com o título $O$ Crucifixo, uma tradução de um artigo editado em Paris sob as iniciais M. F., e posteriormente traduzido por D. Macedo Costa, o texto expressa de modo bastante claro a visão de arte para bispo do Pará. À guisa de sermão, com objetivo de exortar os fiéis a seguirem corretamente os preceitos morais da Igreja, o prelado desenha um esforço comparativo em torno das representações artística entre Cristo e Vênus, entre o catolicismo e paganismo, entre religião e mitologia. 
O texto começa narrando a relação de Alberto e Maria, cristãos exemplares e fervorosos, que não temiam em mostrar-se como tais: "Vão junto à igreja, rezam e comungam juntos". $O$ casal era tão fiel aos valores católicos que chegou a transformar o próprio quarto num pequeno santuário: "Tudo nele respirava o perfume da virtude". Lembre-se que virtude era um termo chave na visão do bispo acerca das artes, virtudes cardinais, humanas ou teologais. Mas, continuemos com a história. Ali havia um grande Cristo de marfim que protegia e dominava o leito dos esposos. Fazia parte da sóbria decoração do quarto uma estampa da Santa Virgem, que ficava suspensa acima de um genuflexório e dava mostra de uso frequente. Além das imagens sacras, figuravam quatro retratos de família, "os do pai e mãe de cada um, que eram, como o do Cristo e o da Virgem, os únicos quadros que ornavam este modesto recinto". Entre a guarnição da alcova, havia ainda um relógio sobre o qual se via um anjo da guarda que cobria "com suas asas o berço de um menino adormecido". Nesse ambiente íntimo de paz, eles viviam então felizes. Ao completarem um ano de casados, a jovem esposa teve o pensamento de dar "um presente a seu marido, e lhe ofereceu um bonito quadro de madeira esculpida, um delicioso Crucifixo, verdadeiro objeto d'arte". Segue-se assim um diálogo entre o casal, demonstrando como utilizar o objeto sacro que adquirira: "Nós o poremos, lhe disse ela, lá por cima do relógio, e ele presidirá as nossas íntimas conversações e as abençoará". Tendo concordado com a ideia, Alberto agradeceu à mulher, beijando o crucifixo, e com o acento de fé lhe respondeu: "Tens razão, Maria: o Cristo nos faltava nesse lugar. Agora que o puseste aí, nós o teremos sempre diante dos olhos".

No decorrer da crônica aparece Victor, um personagem que, na verdade, é o contraponto de Alberto. Tendo sido seu condiscípulo no colégio, Victor, diz o cronista, era um homem de talento, mas estava longe de partilhar das ideias religiosas de Alberto, e bem pouco se parecia com ele. Reforçando em seguida: "Victor é um artista, mas um artista de espírito forte. Não sei mesmo se ele crê em Deus!" Uma noite, ao visitar Alberto em sua residência, Victor se mostra incomodado com a profusão de crucifixos espalhado pelos compartimentos da casa, principalmente no quarto; reprova Alberto por tão desproporcional exibição dos sentimentos religiosos. Alberto, surpreso com o comportamento do artista, logo procura justificar o motivo de ter aqueles objetos ali. Porém, insatisfeito com a explicação, Victor indaga novamente o católico fervoroso: "Mas para quê precisas de tantos crucifixos?" Depois disso, começa um longo debate que contrapõe a arte religiosa à arte profana, exalta a virtude da primeira e ressalta os efeitos deletérios da segunda. Na preparação dos argumentos, Alberto não perde tempo e interroga Victor a respeito dos objetos artísticos que possuía em casa:

- Escuta Victor, e não te zangues, porque foste tu que começaste o debate

- O que queres tu dizer?

- Não tens em tua casa algumas pinturas que tu estimes muito?

- Minha Vênus-ao-levantar?

- Justamente.

- É simplesmente uma obra primorosa. Seus coloridos, tons, carnes, tudo parece vivo. 
- Tens também sobre tua mesa um mármore que parece ter a teus olhos muito mérito.

- Minha Vênus-do-Cisne?

- Isso mesmo.

- É uma obra prima de um acabado perfeita. Não notaste a sua delicadeza e a sua graça?

- E o bronze que orna o teu lar?

- Minha Vênus-no-banho?

- Sim.

- Um bronze de arte, uma perfeição. Não conheço nada mais delicado.

- E perto do retrato de tua mulher, aquela miniatura faceira, que tu acaricias tantas vezes com o olhar?

- Minha Vênus-do-jogo, perseguida pelo amor?

- Tu o disseste.

- Um diamante, uma pérola: um modelo admirável de formas elegantes e pureza de estilo.

- Eu creio.

- Seria bem difícil, e eu te lastimaria se pensasses ao contrário (O CRUCIFIXO, 1863, p.5).

Ao fazer Victor enumerar as obras que possuía em seu gabinete, Alberto procura mostrar a contradição do artista, que teria sido intolerante com os dois crucifixos que ele tinha em casa, enquanto dispunha de quatro "formosas e soberbas Vênus". Victor então alega que havia diferença entre os dois casos, porque, no caso dele, era "negócio da arte". Alberto responde no mesmo tom, desafiando Victor em seguida: "E quanto a mim, é um negócio de religião. Qual vale melhor? Responde?" Victor, numa manobra evasiva, retruca: "A arte desculpa tudo". Percebendo a intransigência de Victor, Alberto apela para possíveis danos de ordem moral que a coleção de Vênus do artista poderia causar à sua própria família, especialmente à filha:

\footnotetext{
- Crês isto bem? Toma cuidado, Victor. Tua filha vai crescer: daqui a dous ou três anos ela parará diante de um dos teus ídolos, e com a curiosidade ingênua da infância, te perguntará quem é esta senhora vestida com tão pouca modéstia. Que lhe responderás? Eu quisera ouvir a tua resposta.

Quanto a mim, não me dão cuidados as perguntas do meu homenzinho: ele poderá falar de qualquer dos meus Crucifixos, e me perguntar o que eles representam e eu poderei satisfazê-lo sem ter necessidade de disfarçar a verdade, sem corar.

$\mathrm{Ah}$ ! Se tu soubesses, Victor, tudo que se encerra na simples Cruz, nessa imagem, nesse Crucifixo que tu não podes ver e que repugnas (O CRUCIFIXO, 1863, p.5).
}

Victor não se dobra diante dos argumentos, mostrando-se cético no momento em que Alberto procura convencê-lo da importância da figura de Cristo em sua vida e o significa do crucifixo para o universo cristão: "Superstição", "imaginação", "quimera" são palavras usadas na crônica por Victor para rebater o discurso cristão de Alberto. Mas o católico convicto não desiste de colocar por terra a incredulidade do artista. Recorre novamente à comparação entre Cristo e as Vênus: contrapõem carne e espírito, sacro e profano, pureza e pecado:

- Crê-me, Victor, não há neste mundo senão duas divindades. 
- Quais são elas?

- Jesus Cristo, e.... adivinha a outra?

- Eu nem mesmo suponho.

- Tu povoaste com ela a tua casa.

- Que queres tu dizer com isso?

- Quero dizer que não há senão Jesus Cristo, e Vênus.

- Singular ideia!

- É verdade: quando se deixa de adorar Jesus Cristo é para se adorar a carne (O CRUCIFIXO, 1863, p.5).

Victor se irrita com essas colocações, consideradas insulto à sua pessoa. Contudo, Alberto continua a argumentar, até que os dois finalmente adentram o campo movediço do significado da arte:

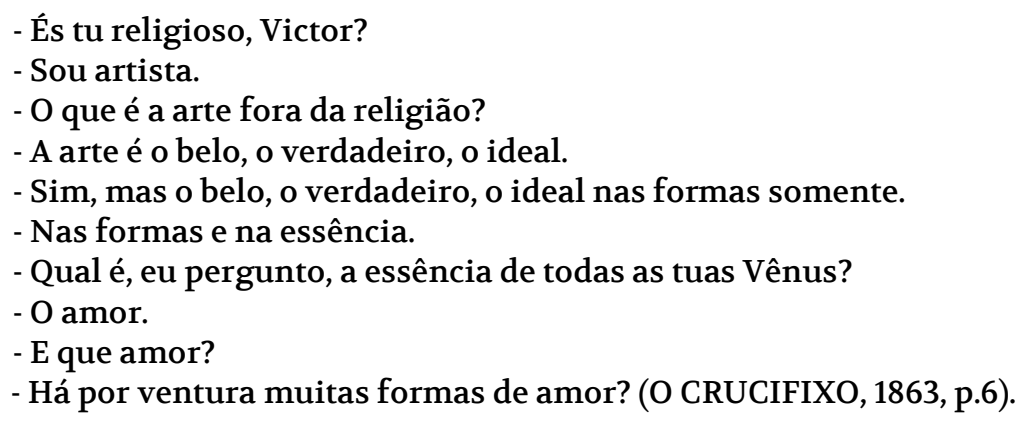

É neste ponto que Alberto diz ter esperado que Victor chegasse. Explica então que há toda sorte de amor, como o egoísta amor carnal, mas nenhuma se compara com o amor espiritual despertado pelo crucifixo, porque ele mesmo é 'o princípio do amor'. Victor então replica: “Eu prefiro o outro". Alberto diz que o amigo pensa dessa forma porque não sabe "o que é amar cristãmente, amar debaixo dos olhares de Jesus Cristo"; que não "sabe o que é ter-se um Crucifixo por laço de amor". Como uma última tentativa de convencer Victor do poder transformador do crucifixo, Alberto insta o artista a experimentar, ao lado de sua mulher, a ajoelhar-se diante do crucifixo e fazer uma oração. Com essa experiência, Victor conheceria "toda a virtude, isto é, toda a força e poder que tem um Crucifixo". No dia seguinte a essa conversa, Maria levava à mulher de Victor um crucifixo. "O que se passou?"- indaga o cronista a fim de chamar a atenção dos leitores para o final da história. Em menos de um ano depois do fato, Victor teria transformado completamente a sua vida. Os sinais de mudança não podiam ser mais evidentes: as Vênus, tão apreciadas pelo artista, "tinham desaparecido para dar lugar a objetos religiosos graves e austeros”; Victor ia à missa, confessava-se e sua única ambição era tornar-se "um esposo Cristão, um pai Cristão, um artista Cristão". Mudança que se estendia à família: "Sua mulher, de dia e de noite mais respeitada, tornou-se de dia em dia mais feliz, e voltou de novo à piedade da primeira infância". Quanto à filhinha, "aprendeu a orar, e as primeiras palavras que pronunciou foram os nomes sagrados de Jesus e Maria". Mas 
os efeitos da conversão ultrapassam esses limites. Num momento em que a arte deve estar subordinada à religião, o artista se inspira nos valores cristão e nele busca a renovação de seu ofício: "Victor veio a ser não só um homem de talento, mas um artista de gênio...". Para finalizar o texto latino: $\mathrm{O}$ crux ave, spes unica, ou seja, Salve ó Cruz, única esperança (O CRUCIFIXO, 1863, p.7).

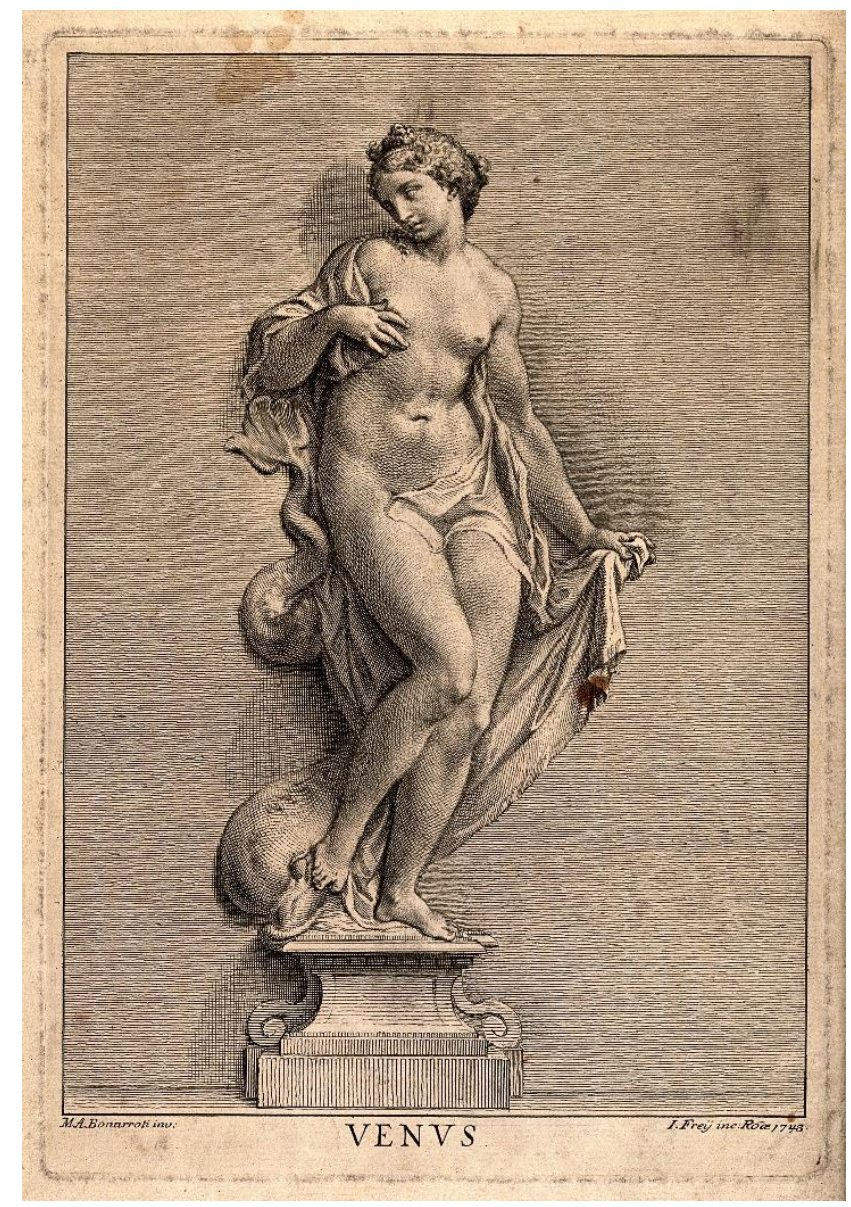

Figura 2: J. Fray, Venus, c. 1743, gravura a partir de Michelangelo Buonarroti. (Arquivo da Cúria Metropolitana de Belém).

O longo texto sobre Alberto e Victor, sobre as escolhas entre o Crucifixo e Vênus, ou sobre uma arte religiosa e uma arte profana, de fato apenas espelhava um debate muito mais profundo. $\mathrm{O}$ tema era a chamada reforma católica e todo um projeto de aproximar a igreja vivida no Brasil das prerrogativas defendidas pelo papado de Pio IX. O campo envolvia o uso da iconografia na esfera religiosa. De fato, se tratava de uma contenda sobre os espaços globais da arte, de Roma como epicentro da cultura artística sacra e o mundo inteiro em sua órbita. A chamada romanização católica, não sem sentido, foi apontada por alguns autores como um momento de globalização do catolicismo e de retorno a um projeto de igreja 
universal (CASANOVA, 1997). O bispo do Pará D. Antonio de Macedo Costa, neste sentido, não somente foi articulador de programas icolonógicos para os antigos templos de Belém em comum acordo com as novas diretrizes do Vaticano (RODRIGUES, 2015), como também foi o promotor de um processo de desmontagem e remontagem dos pradrões decorativos de diversos templos da Amazônia, incluido Belém e Manaus, manejando o que Didi-Huberman mais recentemente chamou de "astucia da imagem" e todo o conhecimento e abstração que advêm pela montagem narrativa do objeto iconográfico (DIDI-HUBERMAN, 2015, p.130-1).

O texto incentivando a devoção ao crucifixo e exortando pelo expurgo de Vênus, como imagem profana, também faz parte do mesmo processo de reforma dos padrões e modelos do catolicismo brasileiro, especialmente entre as décadas de 1860 e 1880. A promoção de "novas" devoções, substituição de imagens, valorização de arquétipos e hagiografias e eleição de uma arte acordada com os novos parâmetros artísticos do catolicismo romano ao tempo de Pio IX são obras de profundo impacto levadas a cabo pelo prelado do Pará. Uma reforma na Sé de Belém, acompanhada com reformas igualmente profundas na antiga Igreja e Seminário de Nossa Senhora do Carmo e Igreja e Colégio de Santo Antonio são ao mesmo tempo climax e conflito do longo episcopado de D. Macedo Costa (RODRIGUES, 2015; FIGUEIREDO; tRINDADE, 2015; FIGUEIREDO; RODRIGUES, 2016). Essas reformas, juntamente com outras realizadas no mesmo período do pontificado de Pio IX, em vários países do mundo cristão, perfazem um programa iconológico e um corpus narrativo de fundo artístico e sagrado, que são testemunhos da pedagogia e dos debates políticos na história do catolicismo romano (ESPOSITO, 1979), da arte sacra em escala mundial e de um mercado global de arte (CAPITELLI, 2012) e do próprio catolicismo brasileiro do século XIX (NEVES, 2009; RODRIGUES, 2015).

Quem era, no entanto, D. Antonio de Macedo Costa para tanta eminência? Nascido em Maragogipe, na Bahia, em 1830, ingressou no seminário de Salvador em 1848, seguindo depois para França onde deu continuidade aos seus estudos eclesiásticos, entre 1852 e 1854 , primeiramente no Seminário de Saint Celestin, em Bourges, e posteriormente, entre 1854 a 1857, no Seminário de Saint-Sulpice, em Paris. Lá mesmo, em Paris, ordenou-se presbítero no dia 19 de dezembro de 1857, aos 27 anos, pelas mãos do Cardeal Arcebispo de Paris, François Nicholas Madeleine Morlot (1795-1862). Dois anos depois concluiu seu doutoramento em Direito Canônico pela Pontifícia Universidade Gregoriana, em Roma, no dia 28 de junho de 1859. De volta ao Brasil, foi indicado para o episcopado pelo arcebispo da Bahia e Primaz do Brasil, o paraense Dom Romualdo de Seixas (1787-1860), tendo seu nome sido apresentado pelo Imperador Dom Pedro II à Santa Sé em março de 1860. Ainda em 1860, o Papa Pio IX (17921878) confirmou a nomeação do padre doutor Antônio de Macedo Costa como $10^{\circ}$ Bispo do Pará, sendo ordenado como chefe espiritual da diocese paraense no dia 21 de abril de 1861, em solenidade dirigida pelo Internúncio Apostólico no Brasil, Dom Mariano Falcinelli Antoniacci (1806-1874). No mês seguinte, dia 23 de maio, D. Macedo tomou a posse no bispado por procuração, chegando a Belém no dia 24 de julho. Sua entrada solene na catedral paraense deu-se no dia 10 de agosto, dia de São Lourenço, mártir do cristianismo, e fez publicar no 
mesmo dia de sua entrada sua primeira Carta Pastoral, com data de $1^{\circ}$ de agosto de 1861 (NEVES, 2009; FIGUEIREDO; RODRIGUES, 2016, p.978).

Essa trajetória foi apenas o início da carreira de um dos líderes da Igreja Católica no Brasil do século XIX e figura proeminente no movimento de romanização do catolicismo brasileiro. Também chamado de ultramontanismo, esse projeto se referia a uma espécie de doutrina católica que buscava o papado ou a Igreja de Roma como sua principal referência política e religiosa. De fato, o termo latino ultramontanus, que significava "além das montanhas", especificamente, para além dos Alpes de quem está em França ou na Alemanha, reforçava e defendia o poder e as prerrogativas do papa em matéria de disciplina e fé. Nomes como Joseph de Maistre (1753-1821), Louis Veuillot (1813-1883), Hughes de Lamennais (1782-1854) e Emmanuel d'Alzon (1810-1880) estiveram entre os mentores intelectuais romanizadores. De um modo geral, esse movimento católico pretendia contrapor-se ao sistema galicanista que, em Paris, como em outras partes do mundo, defendia diferentes versões de regalismo, com uma aproximação maior da Igreja católica com os estados nacionais, como josefinismo austríaco ou o febronianismo alemão, ou ainda conciliarismo, que subordinava a autoridade do papado ao de um conselho de bispos (OAKLEY, 2003, SANTOS, 1992). Recorde-se, também, o conteúdo político do ocorrido na Alemanha em oposição ao Kulturkampf, movimento anticlerical iniciado pelo chanceler por Otto von Bismarck, em 1872 (GROSS, 1997).

Todo esse referencial político e teológico, de transito internacional, é fundamental para se entender o campo simbólico e as narrativas em torno da circulação de obras de arte europeias, modelares no discurso romanizado, entre a Europa e a América Latina no século XIX, seus modelos, suas ênfases, seus enfretamentos. Na defesa da soberania da Igreja diante do processo de secularização, a arte a serviço da religião exerceria seu papel nos recantos mais longínquos do mundo, estabelecendo noções de "centro" e "periferia" do cristianismo, como foi o caso da capital do Pará, então enriquecida pela exploração da borracha e sua exportação para o mercado internacional (SARGES, 2000). Aqui argumentamos que esse processo de circulação de obras de arte e modelos devocionais foi fundamental na propagação não somente de uma estética tributária dos sentidos propostos pelo catolicismo romano, mas também sobre os intercâmbios, trocas e experiências sociais em torno da arte religiosa na Amazônia. Neste contexto, em cada gravura, pajela, retabulo, altar ou tela desembarcaria na capital do Pará o que havia de mais atualizado no ambiente artístico italiano, havido então como epicentro e matriz da arte sacra e religiosa do mundo cristão no ocidente. Uma obra pintada por artista do círculo papal seria, portanto, o ponto de partida na difusão das linguagens artísticas comuns à doutrina da Sé Romana. D. Macedo Costa, por seu turno, impunha-se como o idealizador de um programa iconológico para reforma de toda a decoração da catedral, ponto alto de seu episcopado. Importante enfatizar que este templo tinha uma vasta vida pregressa e que a mudança das telas, aqui analisadas, fazem parte de um processo muito mais amplo. 


\section{Cultuar a Santa Cruz e o Coração de Cristo.}

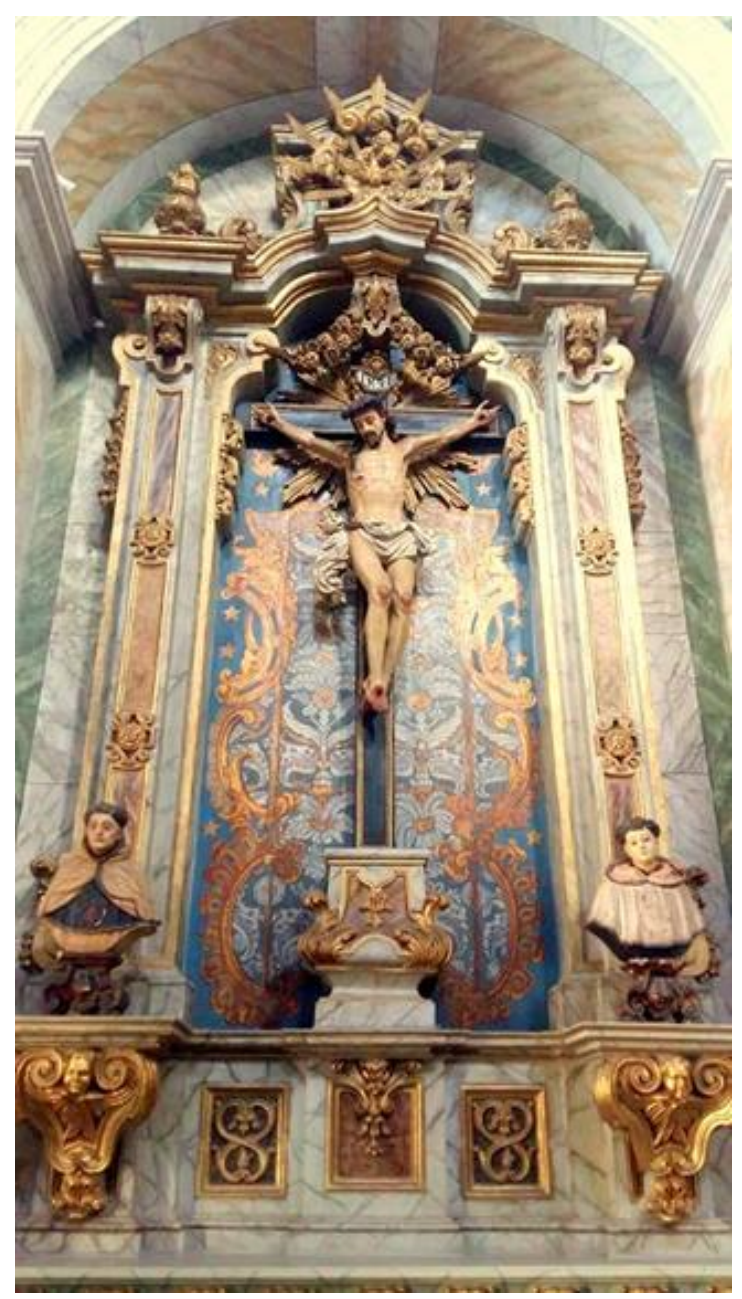

Figura 3: Retábulo e Altar do Crucifixo, Igreja de Nossa Senhora do Carmo, Belém. (Fotografia: Aldrin Figueiredo, 2017).

Não bastava lançar fora a imagem de Vênus, como simbolo do paganismo, D. Macedo Costa estava mais empenhado ainda em substituir as antigas devoções populares tradicionais por novas devoções importadas da Europa, como o Sagrado Coração de Jesus e à devoção à Santa Cruz (MAUÉS, 1999). Ao lado disso, figurava também a criação de novas associações religiosas, como Apostolado da Oração, as Congregrações Marianas e a Pia União das Filhas de Maria, simbolos do novo credo e da nova cristandade (SOUZA, 2010). Ao mesmo tempo, a reforma do ensino dos seminários e o envio de jovens mais promissores para completarem sua formação na Europa, especialmente em São Suplício, na França, e na Pontifícia Universidade Gregoriana, em Roma, completavam os círculos espiritual e mental da reforma.

Tudo isso, bradava o bispo, visava melhorar o nível intelectual do clero nativo. Dentro dessa mesma política ainda ganhou corpo o incentivo à vinda para o Brasil de ordens e 
congregações religiosas europeias, femininas e masculinas, para suprir a necessidade de novos religiosos capazes de atuar no ensino, tanto de seminários como de colégios católicos, nos hospitais, na evangelização e no controle de centros de devoção popular, como é o caso de Belém com a devoção de Nossa Senhora de Belém (MAUÉS, 1999, p.121). No caso de Belém, destacam-se às Irmãs Doroteias do Sagrado Coração, os Irmãos Maristas e os Padres Salesianos, que futuramente iriam dirigir os templos aqui citados à excessão da catedral. É bom reiterar que as atitudes do bispo paraense em relação ao catolicismo tradicional e suas imagens de devoção ficariam mais evidentes na década de 1870, quando da chamada Questão Religiosa, tensionado a igreja católica e a maçonaria (VIEIRA, 1980; MAUÉS, 1999; NEVES, 2009).

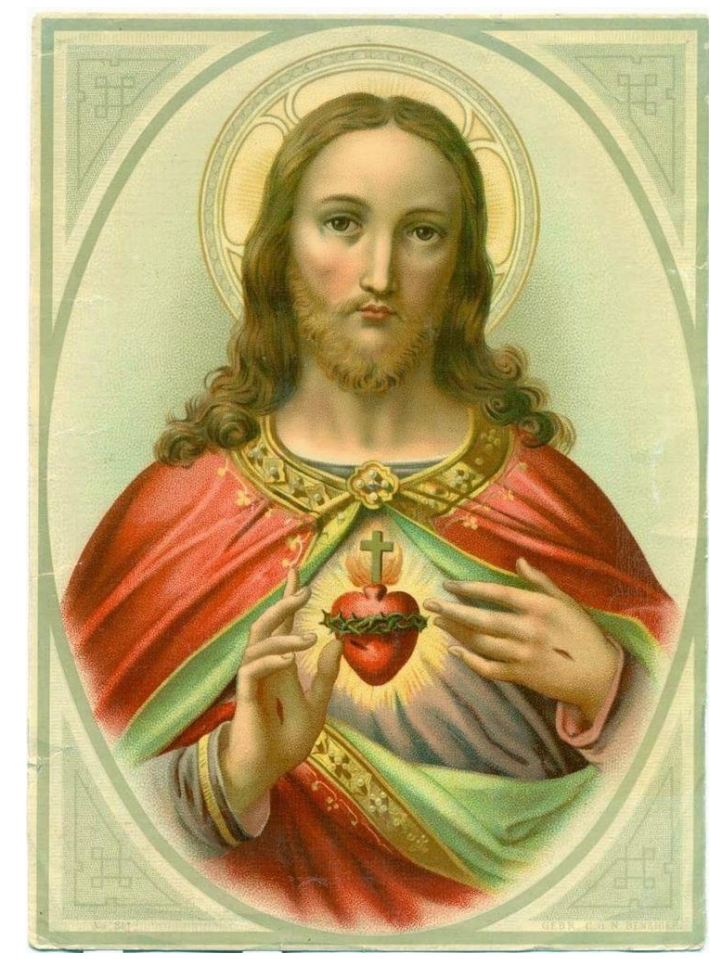

Figura 4: Pajela do Sagrado Coração de Jesus, século XIX, França (Coleção Irmãs Dorotéias, Colégio Santo Antônio, Belém) 


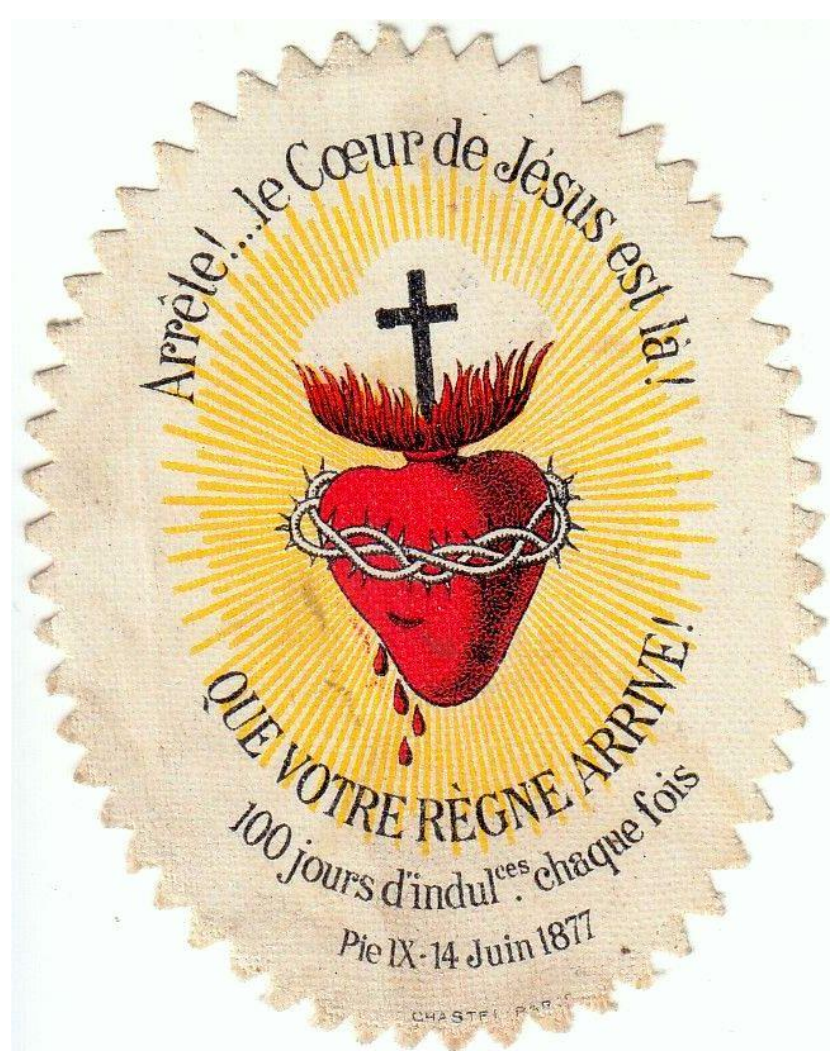

Figura 5: Sagrado Coração de Jesus, Indugências pelo Papa Pio IX, 14 de junho de 1877 (Coleção Paula Ramos Chaves, Belém-PA).

Temos um bom termômetro desse clima de tensão nas matérias publicadas pela imprensa opositora a D. Macedo, assim como por suas diversas cartas pastorais. Em 10 de fevereiro de 1873, por exemplo, um articulista do jornal $O$ Santo Officio enumerava o que chamou de "iniquidades" praticada pelo bispo. Em resumo, dizia que bastava lembrar a guerra movida por D. Macedo contra a Coroa do Divino Espírito Santo, que proibiu de ser colocada no altar da Catedral; a imagem do Bom Jesus dos Navegantes, que queria arrancar de sua capela; as imagens de Nossa Senhora do Livramento, de Santa Efigênia e São Elesbão, que "foram expulsas dos altares da Igreja do Carmo", a mesma em que foi colocada no lugar o Crucifixo e a Capela do Sagrado Coração. As antigas devoções, tomadas agora como símbolo do arcaísmo de suas imagens e de seus devotos leigos, incompatíveis com a disciplina e a boa ordem do asilo que o prelado pretendia fundar naquele convento ${ }^{5}$. Em 17 de novembro de 1872, o jornal maçônico $O$ Pelicano havia sido ainda mais duro e detalhista nas críticas aos atos de D. Macedo. Recordava aos "fiéis católicos" a portaria expedida pelo prelado que proibiu que se colocasse, sobre o altar da Catedral, a Coroa do Divino Espírito Santo. Atitude de desprezo que teria deixado o povo indignado. No entanto, "por adulação unicamente", dizia o articulista, por essa mesma ocasião em que se festejava um dos aniversários de Pio IX na Catedral, teria sido colocado um retrato do pontífice num altar, "o que promoveu fortes reclamações dos fiéis

${ }^{5}$ AS ESCRIPTURAS, 1873, p.2. Sobre essa concepção de arcaísmo na história da arte, ver DIDI-HUBERMAN, 2015, p.277. 
e especialmente dos devotos do Divino Espírito Santo". A imprensa da época toma esse fato para questionar o dogma da infalibilidade papal e denunciar a assepsia do culto e das imagens (VAIDADES HUMANAS, 1872, p.3).

Desde a década de 1860, as novas devoções e imagens que o prelado procurou cultivar no seio da população, em detrimento das tradicionais, parecem ganhar espaço nos cultos e nos templos. A exaltação da Santa Cruz ou a devoção do Crucifixo de Nosso Senhor Jesus Cristo é o melhor exemplo disso. Em 1869, exatamente no dia 15 de setembro, o bispo D. Macedo Costa publica sua Carta Pastoral a partir de Roma a fim de assistir ao Concílio Ecumênico, assinada sob o selo das armas episcopais na festa da exaltação da Santa Cruz, a ser comemorada nas igrejas de Santana, Santo Antonio, Santíssima Trindade, além da Catedral de Belém (GOVERNO DO BISPADO, 1869, p.1). Dez anos depois, o almanaque do Diário de Belém já agendava para o domingo, dia 14 de setembro, a festa do Nome de Maria e Exatação da Santa Cruz, com data fixa do calendário católico paraense (ALMACH, 1879, p.34). Bem antes disso, o jornal oficial do bispado $A$ Estrella do Norte trazia artigos com forte perfil doutrinário em relação ao culto da Santa Cruz. Em 1864, o assunto era uma perigrinação de um "jovem perdido" a Jerusalem para a exaltação da cruz e as revelações de fé em meio a "horrorosas desordens durante a viagem" (PERDIDO NO DESERTO, 1864, p.7).

Recado dado, a Cruz deveria ganhar mais espaço em todos os templos. No final da década de 1870 o projeto ganha corpo. Isso pode ser visto, por exemplo, na Semana Santa de 1881. Estando a Catedral em reforma, as celebrações ocorreram em outros templos de Belém, como igrejas do Carmo e Santo Antônio. Contando com grande afluência do povo, as festas religiosas foram "imponentes" e as procissões, "extraordinárias", segundo a matéria do Diário de Notícias, de 19 de abril. Entre todas, porém, a que mais chamou a atenção dos fiéis foi a devoção às "Três horas da Agonia", um culto implantado por D. Macedo no seu projeto de romanização. Na ocasião, a igreja de Santo Antônio, onde ocorreu a celebração, como de costume, estava decorada com véus e tecidos negros. Enquanto isso, no altar-mor do templo figurava o calvário inteiro como simbolo da devoção e exaltação á Santa Cruz: "um grupo de imagens em ponto natural representando Nosso Senhor Crucificado, Maria Santíssima, S. João e Santa Maria Madalena", tendo atraído "a atenção de todos". Esses icones haviam sido enviados recenteme de uma oficina de Franz Mayer, em Munique, reconhecida em todo o mundo católico por seus trabalhos com vitrais. É possivel que os artistas alemães, da escola purista da Baviera, tenham sido contrados por intermediação da Mayer \& Comp ${ }^{6}$.

\footnotetext{
${ }^{6}$ Se há certeza da proveniência alemã das imagens do conjunto escultórico das Três horas da Agonia, sem uma análise mais detalhada das próprias imagens é difícil saber ao certo a oficina de sua proveniência. Nos registros são citados Franz Mayer \& Comp. e também o Instituto Artístico J. Meyer, ambos situados em Munique (ALTARES, 1881, p.3).
} 


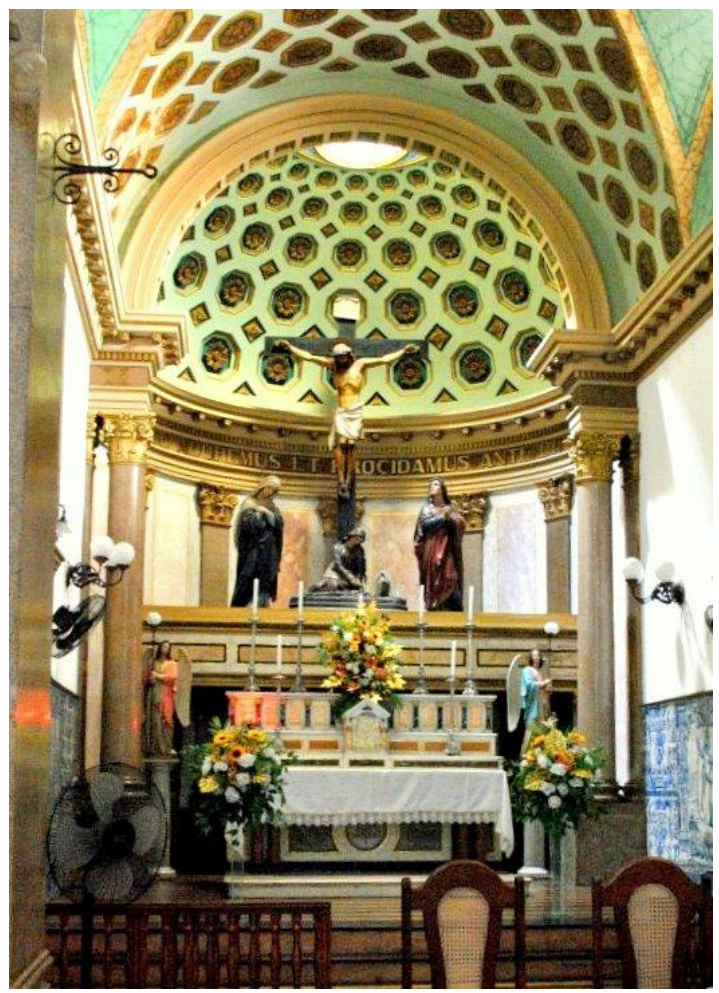

Figura 6: Altar mor da Capela de Santo Antonio, com o grupo escultórico do Calvario, c.1880 (Fotografia Aldrin Figueiredo, 2016).

A respeito da qualidade estética apresentada, acrescenta o articulista: "são um trabalho artístico de súbito merecimento, e, no gênero, nada temos visto aqui que se possa comparar" (SEMANA SANTA, 1881, p.2). Além da beleza plástica, bem percebida pelo redator do jornal, poderíamos incluir o convite à deferência e à meditação que elas deveriam despertar nos fiéis e suas famílias. Não era para menos. Na Amazônia dos anos febris da economia da borracha não faltavam lugares, coisas e pessoas que podiam levar os mais desavisados, sem muito esforço, direto para o largo "caminho de perdição": teatros, botequins, jogos de azar, prostitutas, salões de festa, bebidas "espirituosas" e, talvez mais perigosas, lojas e livrarias abarrotadas de obras com temas liberais e imagens "indecentes". A sombra de Vênus sexualizada estava em toda parte, no teatro e no bordel, nos nomes do vapores que cruzaram o oceano e nas coleções de arte do burgueses paraenses. $O$ jovem Victor, amante da imagem da deusa Afrodite, para os gregos, ou Vênus, para os romanos, não seria apenas um modelo retórico ou um exmplo de folhetim. Em seu Livro da Família, concluído em 1879, é o próprio bispo quem exorta a seus diocesanos a impor "a vigilância cristã". Um "cordão sanitário" que preservasse "o santuário doméstico do flagelo da imoralidade, de todas as pestes a mais temerosa". Assim, no íntimo do lar, eles não deveriam admitir "livros ímpios, heréticos, maus romances, jornais corruptores, poesias e cartas amorosas, estátuas e estampas desonestas, conversas inúteis e indecentes". Ainda, no mesmo tom, conclui: "O lar é um santuário; tudo 
nele deve respirar inocência e virtude" ${ }^{7}$ Se a vigilância cristã aparece como antídoto contra as ameaçadoras ideias e imagens mundanas no seio das famílias, não menos importante era o seu papel no combate à proliferação dessas mesmas ideias e imagens nos espaços públicos por onde todos circulavam (COSTA, 1879).

Na visão romanizada de $\mathrm{D}$. Macedo, a arte, no conteúdo e na forma, deveria estar subordinada à religião, ser expressão da mensagem cristã no seio da sociedade. Dez anos antes desse conflito, em 1867, o bispo lança sua Carta Pastoral do Excellentissimo e Reverendissimo Bispo do Grão-Pará dirigida a seus diocesanos por ocasião de sua volta da cidade de Roma. Um texto detalhado sobre a visão do prelado acerca do papel de Roma como epicentro da cristandade, como modelo civilizatório e sobre o processo de unificação da Itália. A estada em Roma se revelou multipla: Concílio do Vaticano I e as cerimônias dos centésimo oitavo aniversário dos mártires de São Pedro e São Paulo; o momento da inauguração da "Galleria dei Santi e dei Beati" e a "Esposizione romana delle opere di ogni arte eseguite pel culto cattolico"; encomendas de obras de arte sacra a vários artistas ligados à Accademia di San Luca pertecentes ao círculo papal; o interesse e a participação direta do Pio IX no financiamento de um novo altar para a Catedral do Pará; as tropas do exército sardopiemontês às portas de Roma e a tomada da cidade eterna, impedindo a visita do pontífice à obra; um imponente "altar de mármore" sinalizando novas tendências estéticas determinadas a substituir o modelo colonial pela sobriedade clássica romana; por fim, as cerimônias promovidas pelo Vaticano, como a da Imaculada Conceição, cujo dogma, promulgado em 18 de dezembro de 1854, sob o brasão da "Santíssima Virgem", e do Sagrado Coração de Jesus, figurado na estátua de "Jesus Cristo entre dois anjos adoradores" (COSTA, 1867; CAPITELLI, 2008; FIGUEIREDO; RODRIGUES, 2016, p.984).

Entre Roma, Munique, Paris, Lisboa e Belém do Pará um amplo circuito de imagens sacras, publicações religiosas, encomendas tipográficas, projetos escultóricos e uma infidade de objetos de uso litúrgico circulam à mão de padres e leigos, ordens e confrarias religiosas, que inclusive escapam do controle almejado pela cúria paraense. Um conjunto de telas trazido Roma na segunda metade do século XIX, parte execultado pelo suíço Melchior Paul von Deschwanden (1811-1881) e parte posteriormente executado pelo italiano Domenico De Angelis (1852-1900), atendeu perfeitamente aos propósitos ultramontanos. Na nave do templo, hoje com nove telas, há três de autoria de Deschwanden: "Nossa Senhora com o menino Jesus e Santo Antônio", "Sagrada Família entrando no templo" e "Nossa Senhora com o menino Jesus entregando o rosário a São Domingos". Também é de Deschwandqen o painel que representa "Nossa Senhora de Belém", situado no altar-mor. Por volta de 1869 e 1870, D. Macedo Costa havia encomendado ao artista nove telas. No entanto, só chegaram a Belém cinco dessas obras, sendo que uma representando Jesus no calvário não se encontra mais na Catedral, tela essa justamente entronizada nas festas da Exaltação da Santa Cruz, em 1873, conforme o desejo do bispo. Isto tudo era, certamente, um retrato do que acontecia então no

${ }^{7}$ Cf. COSTA, 1879, p.240. Existem diferentes edições e tiragens desta obra, tanto publicadas no Brasil, Portugal, Suíça e Itália. 
movimento de circulação internacional da arte italiana do século XIX, especialmente da arte sacra. $^{8}$

Em abril de 1873, o jornal $A$ Boa Nova dá conta da chegada desse painel acompanhado de outro. Assim, aqui chegou "um representando o calvário, com Jesus morto, tendo ao lado direito, Maria Santíssima e, à esquerda, São João, outro representando Maria Santíssima com o menino Jesus que desse do seu braço para abraçar Santo Antônio de Pádua" (CATHEDRAL, 1873, p.2; MELLO JUNIOR, 1979, p.39). Donato Mello Junior, ao analisar um nota saída na mesma gazeta de 7 de junho daquele ano, afirma que o pintor, por meio de uma carta, informou ter enviado três "pinturas originais", uma delas era a Sagrada Família, estando o restante em fase de feitura. Pouco tempo depois, o jornal anunciava recebimento das obras por D. Macedo. Ente elas, contava uma que "representava Nossa Senhora da Graça, com o Menino Jesus no colo, enquanto dois anjos ajoelhados aos pés da Virgem estão em adoração". Já outro painel representava "a Sacra Família ao entrar no Templo, quando o Menino Jesus tinha doze anos". E, por fim, havia um que "estampava Nossa Senhora com o menino Jesus entregando o rosário a S. Domingos" (MELLO JUNIOR, 1973, p.39). Essas obras chegaram no momento em que D. Macedo é acusado de declarar guerra às devoções tradicionais, sofrendo pressão para prestar conta dos gastos da diocese. Seus aspectos formais são parte integrante de um programa artístico com uma profunda mensagem espiritual. $O$ jogo do azul celeste com as vestes angelicais dos personagens santos domina uma paleta cromática purista ao gosto dos Nazarenos alemães e italianos. Estas imagens vieram dar continuidade a um projeto eclesiástico, iniciado com a troca das telas setecentistas, havidas como resquícios de um passado já sem sentido (RODRIGUES, 2015, p.122-3).

No lugar da velha decoração com pinturas desgastadas na matéria e no estilo - "pobres crostas", "fealdades", para usar os epítetos lançados pelo próprio bispo no jornal da diocese , o prelado foi buscar na capital da arte sacra o que de melhor havia para os seus fins ideológicos. A pobreza que feria a vista no interior do templo daria lugar a um imponente arranjo capaz de reter na memória os dogmas e mártires cristãos eleitos por um papa infalível. Retirar a feiura do tempo era, para lembrar um conceito de Castoriades, expurgar o caos, o sujo, a ruína (CASTORIADIS, 2007, p.39). Essas obras desaparecidas hoje fazem parte daquilo que Vitor Serrão chamou de "cripto-história da arte". Suas ausências são os sintomas de sua eterna presença, como um viso transversal que recorta o tempo (SERRÃO, 2001, p.11). Num ambiente em que o Estado se seculariza, restringindo a esfera de influência da Igreja sobre a sociedade, as artes, pretensamente subordinadas à religião, convertem-se em veículos do projeto reformador do bispo. Não é sem sentido pensar que a grande obra deixada no longo episcopado de D. Macedo Costa, além da fortuna literária, religiosa e política, tenha sido a grande reforma na sede do cabido paraense. Toda a decoração da igreja passaria por uma

\footnotetext{
${ }^{8}$ Para uma leitura da movimentação da historiografia da arte italiana sobre o "Ottocento" com vistas à circulação de artistas no estrangeiro, vale destacar CASTELNUOVO, 1991; AGNELLINI, 1996-1997; CAPITELLI, 2012; E VASTA, 2012.
} 
profunda atualização nos parâmetros do século XIX e da pedagogia artística ultramontana ao tempo do pontificado de Pio IX.

No templo paraense, painéis e retábulos seriam substituídos por "modernas pinturas" e o antigo retábulo-mor de Nossa Senhora da Graça, de feição rococó projetado e executado por Giuseppe Antonio Landi (1713-1791), e que incluía uma tela de autoria do pintor português Pedro Alexandrino de Carvalho (1729-1810), seria substituído por um suntuoso altar em mármore de Carrara da lavra do arquiteto e escultor romano Luca Carimini (1830-1890), havido então como um dos preferidos nos círculos intelectuais do Vaticano. Poucas das antigas telas seriam mantidas pelo bispo. Sua escolha do que "preservar" se deveu a um acurado e delicado programa iconológico que articulava diferentes tradições artísticas em torno de um projeto pedagógico baseado nas virtudes cristãs - cardinais e teologais, expostas arquetipicamente por meio do repertório narrativo da hagiografia dos santos (FIGUEIREDO; RODRIGUES, 2016).

Santos mártires e penitentes, como São Sebastião, Santa Maria Madalena e Santa Bárbara, ao lado de santos guerreiros e pregadores, como São Miguel Arcanjo, São Domingos de Gusmão e Santo Antônio, que enfatizavam as chamadas virtudes cardinais, até as representações marianas da Sagrada Família, de Santa Ana com a Virgem Maria, de Nossa Senhora do Rosário com São Domingos e Nossa Senhora com Santo Antônio. Uma movimentada história da circulação de arte religiosa estrangeira na Amazônia entre os séculos XVIII e XIX não promoveu, no entanto, grande fortuna crítica. Praticamente todos os trabalhos por nós consultados até o momento se baseiam em informações deixadas pelas crônicas de Antônio Ladislau Monteiro Baena, publicadas em 1838 e 1839, e pela memória publicada pelo monsenhor Américo Leal sobre a Catedral da Sé em 1979. Muito recentemente, a pesquisa de Silvio Rodrigues, conectando a história social da arte com os movimentos políticos e religiosos do século XIX, tanto na Itália como no Pará, vêm lançando luz sobre essa questão, corrigindo inclusive atribuições equivocadas, datações apressadas e contextualizações deslocadas no tempo e no espaço em relação a autores e obras 9 .

\section{Uma cópia de São Miguel Arcanjo de Guido Reni na Sé do Pará}

Desde 1869, depois de seu retorno de Roma, D. Macedo Costa investe na subsituição da tela de São Miguel. Escrevendo para o jornal $A$ Estrella do Norte, de 17 de janeiro daquele ano, o bispo afirma que estava sendo "colocado em um dos altares laterais" um painel, recentemente chegado da Itália", encomendado por ele próprio. E mais: "É uma cópia bem acabada do São Miguel, primor de obra do célebre Guido Reni, e cujo original se admira na

\footnotetext{
${ }^{9}$ BAENA, 2004; RODRIGUES, 2015. Pela primeira vez, um trabalho aprofundou a análise de vasto material documental, especialmente publicado pela imprensa brasileira do século XIX, tanto em Belém do Pará como no Rio de Janeiro, entrecruzando as transformações artísticas e a reforma católica realizadas no episcopado de D. Macedo Costa.
} 
igreja dos padres Capuchinhos em Roma. São Miguel vitorioso rechaça para o abismo a Satanás acorrentado". No mesmo tom, aproveita para ressaltar a potência da imagem: "A força e a graça que transluzem no semblante e no porte do Arcanjo, o grandioso e belo horror de seu adversário vencido, contrastam de uma maneira sublime nesta grande composição artística". Um campo de intertextualidade está contido na prédica de D. Macedo Costa. Miguel era um arcanjo, que em sua etimologia original queria dizer mensageiro primeiro ou principal. Anjo da mais alta ordem - a oitava na hierarquia celeste - aparece, no entanto, descrito apenas duas vezes no Novo Testamento da bíblia cristã. Sob o ponto de vista do programa iconológico proposto para a Catedral da Sé por D. Macedo Costa, São Miguel representava a luta pela cristandade e pelos valores do catolicismo romano. Com o santo guerreiro, soldado e militar, o prelado retomava uma emblemática fundamental desde a chamada Igreja Primitiva. As guerras do presente, contra a maçonaria e o liberalismo seriam comparáveis às lutas do santo contra o mal.

O uso de D. Macedo Costa da iconografia dos santos combatentes, como São Sebastião e São Miguel Arcanjo tem também um significado histórico relacionado à política ultramontana e ao pontificado de Pio IX, atualizando-se na luta contra os inimigos da fé e da Igreja, numa especie de imagem-combate, eivada de anacronismos, no sentido atribuido por DIDI-HUBERMAN (2015, p.183). Se a questão também era a modernidade e atualização artística da sociedade e da igreja, parecia inevitável fazer comparações formais com as antigas telas setecentistas portuguesas de Pedro Alexandrino, havidas pelo bispo como antiquadas e esteticamente inferiores. Para tanto, convida "os amantes da pintura a lançarem um olhar naquele formoso painel", que, segundo ele, "lá está protestando contra seus vizinhos, pobres crostas, cujo colorido assanhado e desarmônico é ainda agravado pelo incorreto do desenho". Segue-se um juízo condenatório: "Quando desaparecerão daí aquelas fealdades? Seria coisa tão fácil substituí-las vantajosamente!". O exemplo era "belo quadro de São Miguel”, que teria custado apenas 400.000 réis. Assim, finalmente concluía: "Quando se compreende a necessidade de embelezar um pouco a nossa Catedral, tão nua e tão desonrada, a coisa se fará por sim mesma". Ainda de acordo com o bispo articulista, o painel de São Miguel Arcanjo havia sido adquirido por meio da cooperação do Cura e de "alguns bons paroquianos da Sé". Desse primeiro impulso, esperava-se que o movimento continuasse até o fim das obras, com que muito ganharia em "esplendor o primeiro Templo da Província". ${ }^{10}$

\footnotetext{
${ }^{10}$ A ESTRELLA DO NORTE, 1869, p.1. Uma primeira citação desse documento está em MEIRA FILHO, 1973. p.85-6.
} 


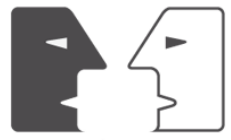

ANTÍTESES

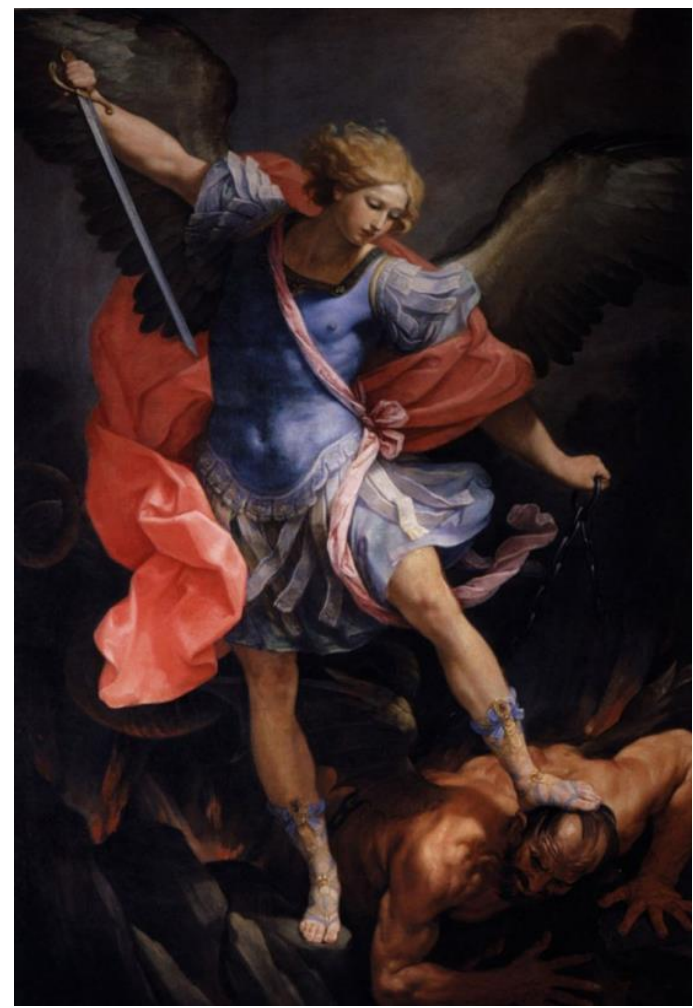

Figura 7: Guido Reni. São Miguel Arcanjo que derrota Satanás,1635.

Óleo sobre tela (2,93 x 2,02 cm). Acervo da Igreja de Santa Maria della Concezione dei Cappuccini, Roma, Itália.

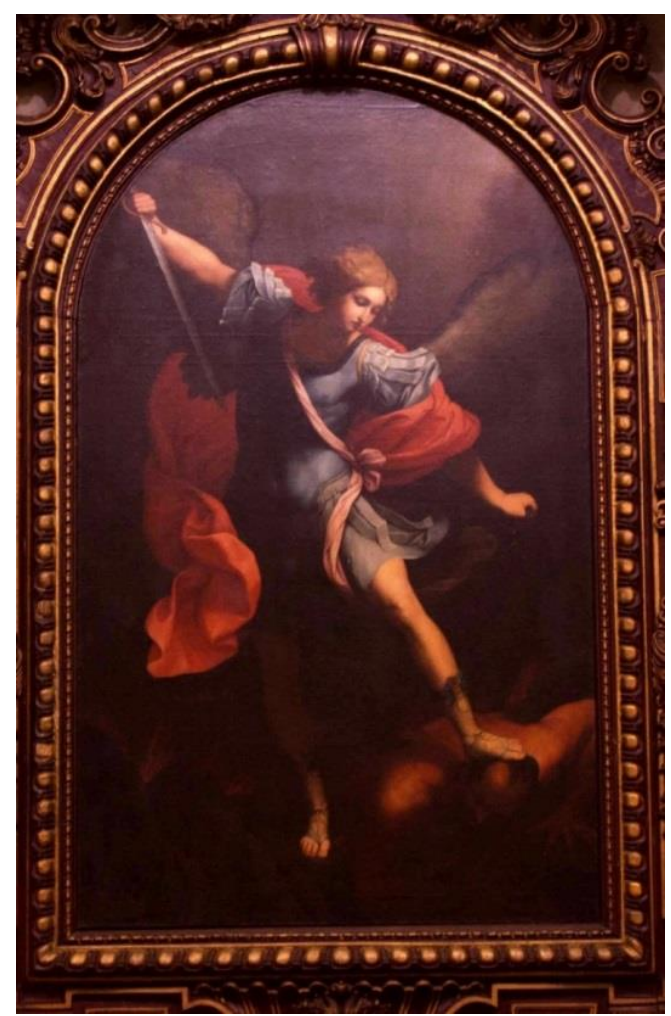

Figura 8: São Miguel Arcanjo, 1868. Óleo sobre tela $(3,20 \times 1,93 \mathrm{~cm})$. Cópia do original de Guido Reni. Autor desconhecido. Acervo da Catedral da Sé de Belém. Fotografia: Silvio F Rodrigues, 2015. 
É claro que aqui a voz fazia eco aos interesses do bispo. O próprio jornal $A$ Estrella do Norte era de propriedade da diocese. Porém, o apelo não se dirigia apenas aos fiéis católicos, mas também ao poder público, num tempo em que o Estado deveria dar o suporte necessário ao estabelecimento e continuidade da religião oficial. A arte foi parte fundamental neste sentido e o mecenato católico moeda de troca entre os poderes temporal e espiritual, ou entre o Estado e a Igreja. Pelo acolhimento positivo dado à cópia de Guido Reni (1575-1642) e o julgamento negativo endereçado às antigas telas portuguesas, poderíamos perfeitamente afirmar que há uma mutação nos valores estéticos da elite paraense. Contudo, isso não bastaria para explicar o interesse do prelado em decorar a Catedral com um painel figurando o arcanjo São Miguel em substituição aos antigos que ali se encontravam. De que valia uma boa cópia por uma tela original? Qual o sentido de autoria na decoração de uma igreja no século XIX? Aos olhos do bispo do Pará, ao que parece, as questões mais importantes eram outras. Além disso, qual o valor de um Pedro Alexandrino na década de 1870? É fato que, mesmo em Portugal, a fortuna crítica de Pedro Alexandrino sofria um forte abalo com a presença de estrangeiros. Em 1846, antes das críticas de D. Macedo Costa, o conde polonês Athanasius Raczynski (1788-1874), que residiu em Lisboa como embaixador do rei da Prússia, entre 1842 e 1848, publicou o livro Les arts en Portugal e fez severas críticas à pintura de Pedro Alexandrino (RACZYNSKY, 1846, p.292).

O grande artista do século XVIII, fortemente influenciado por Pompeo Batoni (1708-1787), agora era havido como medíocre e pobre, mais copiador que criador. ${ }^{11}$ Lisboa setecentista era lembrada como território de contrafacção e cópias clandestinas de arte e literatura estrangeiras ${ }^{12}$. Talvez a questão nem fosse a cópia, pois é exatamente disso que estamos tratando, mas o "clandestino", a imitação inferior da então chamada arte religiosa. Além disso, o próprio barroco parecia em sintonia com a sociedade monárquica liberal, que a Igreja em grande medida queria combater. D. Macedo Costa Costa insistia que os exageros do barroco e do rococó, por sua corporeidade fútil, fundamentada em modismo e luxos das "encenações" e do "teatro das aparências"13. Ainda assim, talvez seja mais fecundo entender o descaso de D. Macedo Costa com a pintura de Pedro Alexandrino, recorrendo ao movimento cultural pelo qual passava a Igreja católica naquele momento, expresso aqui na política intelectual de Pio IX e na exportação da arte sacra pelo mundo.

Trata-se, portanto, de um movimento que acontecia então no mundo católico sob a influência do Vaticano. A historiadora Giovanna Capitelli, que se tem dedicado ao estudo da arte italiana no século XIX, afirma que algumas telas para os altares da Igreja de Nossa

\footnotetext{
${ }^{11}$ RACZYNSKI, 1846, p.292. O trabalho mais completo sobre a obra de Pedro Alexandrino de Carvalho em Portugal e no Brasil é o FONSECA, Op. cit., p.33. Ver também a tese de TAVARES, 2015. Os autores agradecem a Vitor Serrão as importantes indicações sobre a fortuna crítica de Pedro Alexandrino de Carvalho em Portugal.

${ }^{12}$ A questão foi, inclusive, estudada por MARTINS, 2013.

${ }^{13} \mathrm{O}$ modelo, de certo modo, é o mesmo visto em Portugal e condenado pelo clero luso. Em 1863, o Patriarca de Lisboa D. Manoel Rodrigues da Silva (1800-1869) encabeçou um protesto contra a intervenção do governo nas coisas espirituais, incluindo a gestão dos bens artísticos da Igreja. Esse documento foi transcrito em Belém. A ESTRELLA DO NORTE, 1863, p.1-3. Cf. também, sobre os "gostos" no barroco lisboeta, SUCENA, 2007, p.3. No campo artístico, ver SERRÃO, 2003.
} 
Senhora da Assunção, que estava sendo construída em 1859, em Istambul, foram encomendas ao pintor italiano Ignazio Tirinelli del Serrone. É muito provável que a cópia de Reni enviada a Belém seja de sua autoria, exatamente porque seu nome estava no epicentro do circulo de artistas visitados por D. Macedo Costa no final dos anos de 1860 em Roma. Do jovem Serrone se sabe muito pouco, apesar de ter uma vida razoavelmente documentada entre 1833 e 1870 . Formou-se com Tommaso Minardi (1787-1871) na Accademia de San Luca e na juventude, por volta da década de 1840 , era uma bela promessa na pintura sacra italiana. Os temas das telas enviadas à Turquia foram um Santo Inácio de Loyola; um São Francisco Saverio, jesuíta espanhol pioneiro da difusão do cristianismo na Ásia; uma Natividade da Virgem Maria e, por fim, uma cópia de San Michele Arcangelo schiaccia Satana, de Guido Reni, segundo uma prática que, como vimos ocorrer também no Santiago do Chile e Belém do Pará, mesclou pinturas modernas e copias antigas. Por fim, a obra l'Assunzione della Virgine, assinada e datada de 1863, seria a obra mais importante (CAPITELLI, 2012, p.485).

Além disso, D. Macedo Costa, conhecedor dos templos franceses, portugueses e italianos, além de travar vasta correspondência com artistas alemães e suiços, sabia muito bem que a arte vivia de referências, modelos, planos e arquétipos. Seja como for, ainda não temos uma precisa informação documental, mas o pintor Ignazio Tirinelli del Serroni talvez seja o autor da cópia do São Miguel de Reni enviado a Belém, em 1869, tal sua importância na produção de cópias similares e para o mesmo fim, na mesma época e para o mesmo programa de disseminação da chamada galeria vaticana. Del Serrone também havia ganho certa notoriedade pela tela de São João Batista e pelo retábulo com tema da Assunção da Virgem Maria, executados em 1856, para Catedral de Santa Maria da Assunção, em Roma. É certo também, devemos enfatizar, que tanto antes como depois da troca das telas na Catedral de Belém, experientes artistas italianos que circularam no Pará entre as décadas de 1860 e 1890 , todos incentivaram o uso e a valorização de cópias de grandes obras do passado, fosse de um Michelangelo Buonaroti, um Rafael Sanzio, um Guido Reni ou de um Francesco Hayez. A temporalidade da obra pouco importava. O que estava em jogo era o valor, a fama e o gosto que havia alcançado em amplos setores da sociedade. ${ }^{14} \mathrm{O}$ lastro político e estético do bispado de D. Macedo Costa e do pontificado de Pio IX podemos dizer que era herdeiro de certa tradição dos centros artísticos italianos, tanto em Roma, Veneza, Florença, Milão, Turim ou Gênova, principais redutos de intercambio artístico com Belém do Pará no século XIX. Além disso, D. Macedo também mimetizava, em certa medida, as coleções dos famosos cardeais da passagem do século XVI para o século XVII, em cujas pinacotecas Guido Reni era festejado, como por exemplo, do cardeal Scipione Caffarelli-Borghese (1577-1633) e do cardeal Giovanni

\footnotetext{
${ }^{14}$ Importante conferir o catálogo organizado por MOURA, 1895, p.97; FIGUEIREDO, 2011, p.53. Ignacio Moura se refere às cópias realizadas por Domenico De Angelis de uma "Madona" de Rafael para a grande exposição do Lyceu Benjamin Constant em 1895. Aldrin Figueiredo analisa a importância da cópia da tela $o$ Beijo de Francesco Hayez, c.1895, pertencente ao acervo do Museu de Arte de Belém.
} 
Battista Maria Pallotta (1594-1668), nomes muitas vezes referido pelo bispo do Pará com sinônimos de bom gosto estético. ${ }^{15}$

Num amplo jogo de imagens aceitas ou rejeitadas pela cúpula da igreja paraense, sob o riscado de Roma, está na verdade o esquadro da chamada "grande arte" europeia. As famosas vênus de Ticiano, muitas das quais circulando em cópias de gravuras, abominadas pelos padres em público mas cultivada em suas próprias coleções particulares. Imagens, em pintura, escultura ou estampas de papel das "novas devoções" da Santa Cruz e do Sagrado Coração de Jesus, em moldes trazidos principalmente da Alemanha, França e Itália. Substituição de antigas pinturas portuguesas por modernas cópias italianas, nas quais o nome de Guido Reni sobressaía com extrema potência e vivacidade. A cultura material da fé jamais seria a mesma depois da longa e atribulada reforma católica que tanta marca deixou nos templos do Pará. A circulação de imagens e artistas, amplos debates sobre programas decorativos desenhados nos círculos intelectuais romanizadores da Igreja Católica no século XIX, em Roma, Paris, Munique, Lisboa e Belém do Pará, está claro, fazem parte de um mesmo movimento internacional de cultura visual. Repelir uma Vênus por um Crucifixo, importar Cruzes e Corações Sagrados, ou trocar imagens de anjos guerreiros estão longe de representar um aporte estético da realidade. Aqui a arte é, fundamentalmente, eivada de tensões sociais e políticas. Cruzes, corações e anjos que viajavam na galeria vaticana de Pio IX, ou mesmo em nótorios paquetes e vapores que cruzavam o Atlântico, eram algo para além de mensageiros de Roma nas terras mais longínquas da Amazônia brasileira.

\section{Referências}

\section{Fontes Impressas.}

ALMACH administrativo, mercantil, industrial e noticioso da Província do Pará para o anno de 1869. Coordenado por Carlos Seidl e Octaviano José de Paiva. Pará: Editores Carlos Seidl \& Cia, 1969.

ALTARES - Três horas da Agonia. A Constituição. Belém, 13 de abril de 1881, p.1.

AS ESCRIPTURAS fulminando o sr. Bispo. O Santo Officio. Belém, 10 de fevereiro de 1873, p.2.

A ESTRELLA DO NORTE. Belém, 25 de junho de 1863, p.1-3.

A ESTRELLA DO NORTE. Belém, 17 de janeiro de 1869, p.1.

CATHEDRAL. A Boa Nova. Belém, de 16 de abril de 1873, p.2.

\footnotetext{
${ }^{15}$ A respeito dos cardeais colecionistas do século XVI e XVII, referidos pelo bispo D. Macedo Costa, ver NEGRO, 1996, e
} SGARBI; PAPETTI, 2009. 
COSTA, Antônio de Macedo. Pio IX Pontífice Rei. Lisboa: Typographia de J. J. Carvalho, 1861. . Resumo da História Bíblica ou Narrativas do Velho e Novo Testamento. Einsiedeln, Suiça: Benziger Typografos da Sancta Sé Apostolica, 1875.

_ _ _. O livro da Família: ou explicação dos deveres domésticos segundo as normas da razão e do Cristianismo. Petrópolis: Typ. Vozes de Petrópolis, 1879.

ENCYCLICA do Summo Pontífice Pio IX publicada a 8 de dezembro de 1864. Lisboa: Typographia da Fé Catholica, 1865.

GOVERNO DO BISPADO. Carta Pastoral do Exc. Bispo do Pará ao partir para Roma a fim de assistir ao Concílio Eccumênico. Diário de Belém. Belém, 17 de setembro de 1869, p.1.

O CRUCIFIXO. A Estrella do Norte. Belém, 29 de novembro de 1863, pp. 381-383.

O PENITENTE DO DESERTO. A Estrella do Norte. Belém, 15 de maio de 1866, p.7.

O SYLlABUS ou A Doutrina de Roma. Porto: Typographia de Antonio José da Silva Teixeira, 1873.

PADARIA. Gazeta Official. Belém, 10 de fevereiro de 1860, p.4.

REPARTIÇÃO DA POLÍCIA. Gazeta Official. Belém, 3 de abril de 1860, p.1

SEMANA Santa. Diário de Belém. Belém, 19 de Abril de 1881, p.2.

Variedade. Uma noite no Club. Jornal do Pará. Belém, 5 de novembro de 1867, p.2.

VAIDADES humanas. $O$ Pelicano. Belém, 17 de novembro de 1872, p. 3.

VARIEDADES - Busto de Nosso Senhor. A Estrella do Norte. Belém, 27 de março de 1864, p.6-7.

\section{Bibliografia.}

AGNELLINI, Maurizio (a cura di). Ottocento italiano: pittori e scultori, opere e mercato. Milano: Istituto Geografico De Agostini, 1996-1997.

ALEXANDRE-BIDON, Danièle. Une foi en deux ou trois dimensions? Images et objets du faire croire à l'usage des laïcs, Annales HSS, 53e année, 6, nov.-déc. p. 1155-1190, 1998.

ARSCOTT, Caroline; SCOTT, Katie (eds.). Manifestations of Venus: art and sexuality. Manchester : Manchester University Press, 2000. 
BAENA, Antônio Ladislau Monteiro. Compendio das Eras da Província do Pará. Pará: Typographia de Santos \& Menor, 1838.

_ _ _ . Ensaio Corográfico sobre a Província do Pará. Brasília: Senado Federal, (1839) 2004.

CAPITELLI, Giovanna. Raccontare il sacro: la Galleria dei Santi e dei Beati in Vaticano. In: CAPITELLI, G.; MAZZARELLI, Carla (a cura). La pittura di storia in Italia, 1785-1870: ricerche, quesiti, proposti. Milano: Silvana editoriale, 2008, p.195-209.

_ _ _ _. Los "pittores de Pío IX" en Santiago de Chile: os misterios del rosário para la iglesia de la Ricoleta Domenica (1870). In: GUZMÁN, F., MARTINES, J. M. (org.). Arte Americano e Indipendecia. Nuevas Iconografías. Quinta Jornadas de Historia del Arte. Santiago del Chile: Museo Historico Nacional, 2010, pp. 45-60.

Il mercato globale dell'arte sacra nell'Ottocento. Pratiche, committenze, intermediari, artisti. In: CAPITELLI, G.; GRANDESSO, S.; MAZZARELLI, C. (a cura di) Roma fuori di Roma. L'esportazione dell'arte moderna da Pio VI all'Unità d'Italia (1775-1870). Roma: Campisano Editore, 2012, pp. 385-416.

CASTELNUOVO, Enrico. La pittura in Italia: l'Ottocento. Milano: Electa, 1991.

CASTORIADIS, Cornelius. Fenêtre sur le chaos. Paris: Seuil, 2007.

DIDI-HUBERMAN, Georges. Diante do tempo: história da arte e anacronismo das imagens. Belo Horizonte: Ed. UFMG, 2015.

EBERT-SCHIFFERER, Sybille; EMILIANI, Andrea; SCHLEIER, Erich. (a cura di). Guido Reni e l'Europa:fama e fortuna. Bologna: Nuova Alfa Editoriale; Frankfurt: Schirn Kunsthalle, 1988.

ELSNER, Jas. Comparativism in art history. Abingdon: Routledge, 2017.

ESPOSITO, Rosario. Pio IX: la Chiesa in conflitto col mondo: la S. Sede, la massoneria e il radicalismo settario. Roma: Edizioni Paoline, 1979.

FIGUEIREDO, Aldrin Moura de. Janelas do passado, espelhos do presente: Belém, arte, imagem e história. Catálogo. Belém: Museu de Arte de Belém, 2011.

FIGUEIREDO, Aldrin Moura de; RODRIGUES, Silvio. Um altar romano na baía do Guajará: programa iconológico e reforma católica na Catedral da Sé de Belém do Pará (1867-1892). Horizonte, Belo Horizonte, v. 14, n. 43, p. 975-1011, jul./set. 2016.

FONSECA, Anne-Louise G. Pedro Alexandrino de Carvalho (1729-1810) et la peinture d'histoire à Lisbonne: cycles religieux et cycles profanes. Tese de doutorado (História da Arte). Montreal: Université de Montréal, 2008. 
LEAL, Américo. A igreja da Sé. Belém: Falângola, 1979.

LIASSIS, Nora Clark. Aphrodite and Venus in myth and mimesis. Newcastle upon Tyne: Cambridge Scholars Publishing, 2015.

MARTINS, Maria Tereza E. Payan. Livros clandestinos e contrafacção em Portugal no século XVIII. Lisboa: Colibri, 2013.

MAUÉS, Raymundo Heraldo. Padres e bispos em conflito: o processo de "romanização" da Amazônia. In: Uma outra “invenção" da Amazônia. Belém: Cejup, 1999, pp. 119-136.

MEIRA FILHO, Augusto. Contribuição à história de Belém. Belém: Imprensa Oficial do Estado do Pará, 1973.

MELLO JUNIOR, Donato. Antonio José Landi - Arquiteto de Belém: Precursor da arquitetura neoclássica no Brasil. Belém: Governo do Estado do Pará, 1973.

MOURA, Ignacio. A exposição artística e industrial do Lyceu Benjamin Constant - Expositores em 1895. Belém: Typ. do Diário Official, 1895.

NEGRO, Angela. Il giardino dipinto del Cardinal Borghese: Paolo Bril e Guido Reni nel Palazzo Rospigliosi Pallavic. Roma: Argos, 1996.

NEGRO, Emilio; PIRONDINI, Massimo. (a cura di). La scuola di Guido Reni. Modena: Artioli, 1992.

NEVES, Fernando A. de F. Solidariedade e conflito: Estado Liberal e Nação Católica no Pará sob o pastorado de Dom Macedo Costa (1862-1889). Tese de doutorado (História). São Paulo: Pontifícia Universidade Católica, 2009.

RACZYNSKI, Le C. A. Les Arts en Portugal. Paris: Jules Renouard et C ${ }^{\text {a }}$ Libraires-Éditeurs, 1846.

RODRIGUES, Silvio Ferreira. Todos os caminhos partem de Roma: arte italiana e romanização entre o Império e a República em Belém do Pará (1867-1892). Tese de Doutorado (História). Belém: Universidade Federal do Pará, 2015.

SARGES, Maria de Nazaré. Riquezas produzindo a belle-époque: Belém do Pará,1870-1912. Belém: Paka-Tatu, 2000.

SERRÃO, Vitor. A cripto-história da arte: análise de obras de arte inexistentes. Lisboa: Livros Horizonte, 2001.

_ _ _ _. História da arte em Portugal - o barroco. Lisboa: Presença, 2003. 
SGARBI, Vittorio; PAPETTI, Stefano (a cura di). Le stanze del cardinale: Caravaggio, Guido Reni, Guercino, Mattia Preti. Milano: Silvana, 2009.

SCHUTTER, Xavier de. De Byzance à Florence: sur les traces de Pléthon. Louvain-la-Neuve: EME éditions, 2016.

SOUZA, Ioneide. Construindo identidades: a Pia União das Filhas de Maria e o catolicismo romanizado. Anais do XIV Encontro Regional de História. Rio de Janeiro: ANPUH-RJ, 2010, pp.113.

SUCENA, Berta de Moura. Corpo, moda e luxo em Portugal no século XVIII. Dissertação (Mestrado em História). Lisboa: Universidade de Lisboa, 2007, p.3.

TAVARES, Carla Andreia Carvalho. Pedro Alexandrino de Carvalho (1729-1810): caracterização material, técnica e formal da sua obra em telas de altar. Tese (Doutorado em Conservação e Restauro de Bens Culturais). Lisboa: Universidade Católica Portuguesa, 2015.

VASTA, Daniela. La pittura sacra in Italia nell'Ottocento. Dal Neoclassicismo al Simbolismo. Roma: Gangemi Editore, 2012.

Recebido em: 21-06-2017

Aceito em: 24-08-2017 